DOI: https://doi.org/10.47405/mjssh.v6i9.1054

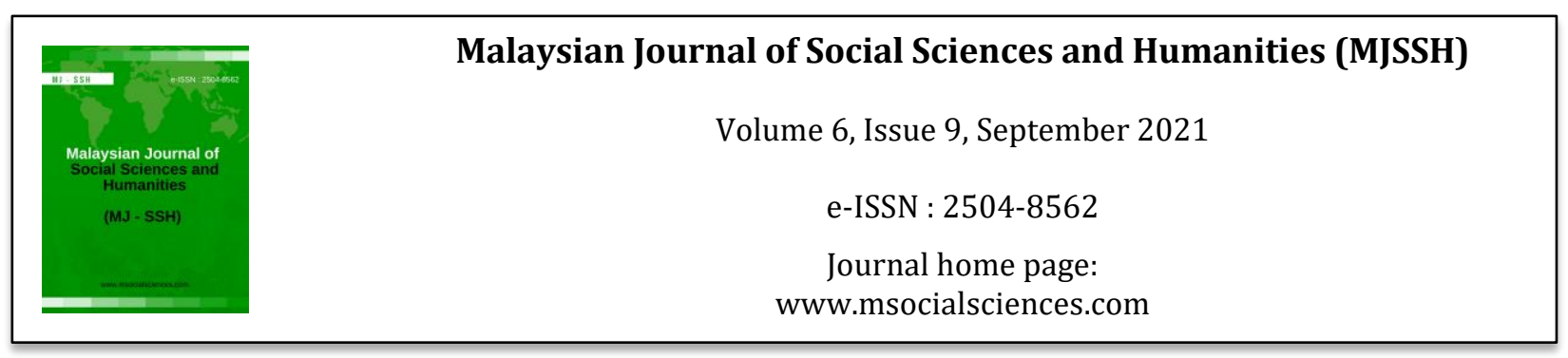

\title{
Interaction In the English Language Classroom: A Review of Teacher Questions
}

\author{
Bala Salisu Abubakar ${ }^{1}$, Shamala A/P Paramasivam ${ }^{1}$, Lee Geok Imm ${ }^{1}$, Sharon \\ Sharmini ${ }^{1}$ \\ ${ }^{1}$ Department of Foreign Languages, Faculty of Modern Languages and \\ Communication, University Putra Malaysia (UPM) \\ Correspondence: Bala Salisu Abubakar (salisubalaabubakar@gmail.com)
}

\begin{abstract}
Teachers' questions in the English language classroom are an essential way of teaching English. Teachers must be aware of the types of questions that can help students learn the target language. Students, on the other hand, did not actively participate in learning, especially when responding to questions from teachers. To address this issue, teachers must modify their questions using various techniques in order to elicit responses from students. This study examines twenty studies selected from the Google scholar on the role of teacher questioning pattern in motivating students' participation in English language classrooms, as well as the classification of modification questions used by teachers when teaching English. We examine current teachers' questioning patterns before reviewing previous research on the most common question type activity in the English classroom. According to the findings, display questions are frequently used by English language teachers as a better approach than referential and other questioning types. Other knowledge-based analyses were discovered to be carried out in order to extract useful features that reduce the risk of better activity, demonstrating that students continue to struggle with high-dimensional and important subjects when answering referential questions. Finally, we highlight some outstanding issues for future research in this area that researchers should consider.
\end{abstract}

Keywords: English language classroom, teacher questioning pattern, students' participation

\section{Introduction}

Teaching is a mutually interactive process between teachers and students that allows them to collaborate to achieve the curriculum's desired learning outcomes (Handeland, 2020). One way of doing that is to ask good questions that allow teachers to get useful feedback on their students' actual progress. Teachers can also encourage students to participate, think, and double-check their understanding by asking them to answer questions that target various levels of rational (Ngadi, 2018). However, some teachers dominate classroom learning by asking students to answer questions that only encourage rote memorization and mechanical drilling of specific language tasks. They may spend most of the class time asking questions that do not require students to think critically, but instead focus on recalling information, speech modifications, and error correction.

One method for gaining students' engagement and interest in the classroom is to ask questions. Questions can be seen as any sentences with an interrogative form or function that are used in 
questioning (Lee \& Kinzie, 2014). In the classroom, asking questions is a conversation form that requires understanding between the speaker and the listener (Nevtria \& Puspita, 2020). According to (Nevtria \& Puspita, 2020), asking questions is essential to use during teaching and learning process because the teacher could indeed guide the class, engage students with the course content, increase participation, and promote understanding by asking questions.

Moreover, Mccomas and Abraham (1991) tend to add that questioning has profound influence on the way that students receive and process the information explained clearly in class. Furthermore, by asking questions, the teachers will get feedback from their student. The feedback is about how well they comprehended the material or lesson that they had learned. Teachers can identify errors in their thinking about content and check students' comprehension towards their learning objectives, which can be represented by students' responses to teachers' questions. According to Khadka (2021) questioning is perhaps the most frequently used method of teaching at all grade levels, and teachers have long used questioning strategies to review, check on learning, explore thought processes, explore problems, discover out different or varying solutions, and challenge students to portray on critical issues or values they had not previously depicted.

Therefore, this present work is aimed to contribute in providing a volume of literature on questions techniques for English language teachers teaching in both senior and junior secondary schools. It discusses recent developments in this field and highlights open issues, as well as the importance of teachers' questioning approaches in problem domain management and providing future direction to incoming researchers. We hope that this article will serve as a benchmark and guide for other researchers looking for a solution in this area.

\section{Overview}

When selecting studies for this review, I looked for published research that examined English language teachers' questioning techniques in second or foreign language classroom interaction in both junior and senior secondary schools. In the classroom, teacher questions inspire learners, increase experience and help to improve awareness and skills for reactionary thought (Nevtria \& Puspita, 2020). It is also important to consider the success of students, to ask questions from teachers. However, this method does not always work well because teachers often neglect to ask questions that allow learners to engage in the interaction. The use of questioning to facilitate the effective learning of students should be considered by teachers. The questioning patterns employed by English language teachers have sparked debate in the classroom. Because such teachers used a lot of high-sounding vocabulary in their patterns, making it difficult for students to understand and respond to the questions, the questioning patterns did not appear to be conducive to students actively participating in classroom interaction. Second, teachers in the classroom use display questions to assess students' comprehension of a given topic (Ngadi, 2018). As a result, students in secondary school find it difficult to communicate effectively in English because they are not fully engaged in the interaction, and they remain only passive learner.

The issue of teacher questioning technique usually catches the attention of the international community, and West Africa is no exception. This is a pressing issue in most African countries where English is the official language and the language of instruction. However, the effective use of the target language to effectively communicate thoughts and ideas is a problem area daily, particularly for young secondary school leavers. Poor English language proficiency among secondary school students frequently draws attention to English language teaching and learning. The main threat, according to the report, is a lack of professionalism in English as a Second Language. It cites numerous instances where teachers in most African countries, such as Kenya and Nigeria, to name a few, have expressed concern about receiving first-year students who can barely write, read, or hold discussions in English (Mutai, 2012). The question is, what happens in secondary school classes that leads to this kind of situation? What are the implications of this situation for an educational system that is heavily reliant on the English language? 
There have also been concerns raised about the inconsistencies between theoretical curriculum standards, rules, and teachers' ideals, as well as the precise questioning pattern used by teachers. According to our research and observations, the way English is taught in secondary schools across Africa, particularly in Nigeria, appears to have an impact on students' overall performance in national exams. That English teachers either do not use or do not apply English teaching skills as specified by the Ministry of Education's curriculum (D \& Oluyemi, 2020). As a result, there is a pressing need to connect teaching skills, particularly oral questioning, to students' English performance. The purpose of this paper is to review related articles and collect data on the oral questioning practices of English language teachers in both junior and senior secondary schools. The main goal is to read through the articles and figure out what kinds of questions English language teachers commonly ask.

\section{Use of Questions in Teaching English Language}

Questioning is probably one of the most adaptable and easily accessible methods in the hands of the teacher. Teachers rely on questioning as an important part of their teaching arsenal, and it may be the most important activity they engage in. In the classroom, teachers ask 86 percent of the questions, accounting for roughly one-third of the conversation (Jumare, 2020). Because English is a language, it is critical to emphasize oral questioning because it improves students' mastery of the language according to the principle of practice makes perfect. Although questions are unquestionably important for teacher and student performance, their effectiveness can be determined by the types and processes they employ, as well as the skill and care with which they are utilised. The teacher's questioning technique has become even more important as the emphasis in educational goals shifts away from rote memorization of facts and information and toward the development of reflective thinking and intelligent material subversion.

These arguments clearly show that oral questioning is only one of the teaching skills that can be effective when combined with other teaching techniques. According to Mutai (2012), the National Curriculum is centred on English. All other learning is predicated on mastery of the fundamental skills of the English language, which are critical not only for educational purposes but also for our economic development. English is emphasized not only as a language of instruction but also as a language of importance because of its importance in the international economic development. The fact most of schools use English as their primary medium of instruction demonstrates the subject's importance in the curriculum as well as a service subject. The latter emphasizes the significance of English in the educational system (Yusuf \& Tambuwal, 2020). The fact that school leavers will need good English in a wide range of occupations, advertisement, and day-to-day exchanges in an international environment are among the various purposes of English.

As previously stated, many studies focus on traditional teaching and learning methods in the classroom. There was little research in secondary schools on using a teacher questioning technique to motivate students' learning strategies. We'll look at a few of them in this section. According to Omari's (2018) findings, regardless of preferred teaching style, schoolteachers use lower-order, higher-order, and follow-up questions on a frequency scale ranging from low to high. Lower-order questions are more likely to be used by new teachers, whereas follow-up questions are more likely to be used by experienced teachers. Even though, it has been proposed that asking lower order thinking questions in a systematic manner will encourage students to speak up and express themselves in the classroom (Dobber, Zwart, Tanis, \& van Oers, 2017; Qashoa, 2013). Again, The majority of teachers observed passed basic questioning processes; however, the majority of teachers failed a unique interaction process; the frequency of questions that facilitate thinking was extremely low, and the score for teachers who qualified to be called prolific questioners was 0/12 (D \& Oluyemi, 2020). However, the data was collected quantitatively via a questionnaire, and participants had a strong tendency to conceal their true responses.

According to another study, 80 percent of teachers' questions were low-level thinking, 77 percent were closed-ended, and 86 percent were display questions. According to the findings, teachers at the upper elementary and secondary levels used more referential questions, and more open-ended questions 
(Jumare, 2020). Despite the fact that the information was gathered via a structured questionnaire, which limited respondents' ability to express their thoughts and opinions on the teachers' questioning patterns in the classroom, the results were still intriguing. This finding supported the findings of Nevtria and Puspita (2020), who discovered that the most frequently asked question by teachers is a knowledge question. After all, several factors, such as the lesson's objectives, the variety of tasks, and the teacher's motivation for asking questions, could all influence the teacher's use of specific question types. First, the objectives of the lesson dictated the teacher's use of specific question types. If appropriate question types are used, learning activities will be successful. As a result, lesson objectives must be carefully designed based on the desired competence and the level of proficiency of the students. It was discovered that the English teacher frequently used remembering questions to test the students' memory. This question type is also used to elicit a factual response, perform recall tests, and recognize information (Muller, Herder, Adamson, \& Brown, 2011).

Furthermore, Teachers' perceptions of questioning-asking as a teaching strategy, as well as the characteristics and types of questions on creating classroom interaction and improving discourse, were found to be positive. In other words, some question types significantly increased classroom interaction while others did not (Rachmawaty \& Ariani, 2019). A further research was conducted by Rachmawaty and Ariani (2019), in which data was gathered through observation and analysed in steps using an interactive data analysis method. According to the findings, teachers asked verification questions more frequently in both classes than critical and concept questions. This is done to ensure that the students understand the topic at hand. Teachers, on the other hand, must recognize that verification questions do not encourage students to think critically or express themselves in English during class interactions. Such questions can only help students remember what they've learned in class (Qashoa, 2013). In a related study, data was gathered through observation, interviews, and videotaping. Out of 241 total questions, the analysis revealed that the teacher asked convergent, closed, and display questions more frequently than divergent, open, and referential questions (Paramartha, 2018). Thus, the primary goal of the teacher's questions is to assess students' knowledge and comprehension while also cultivating students' interest and curiosity so that they can communicate effectively with their peers in the classroom. Questions can help students develop critical thinking skills because they encourage students to think critically and elicit more authentic communication rather than simply recalling facts. Despite the numerous benefits of teacher's questions, teachers do not benefit from them because posing them presents numerous challenges. Teachers who use questions as part of their teachinglearning strategy in the classroom, on the other hand, may experience a variety of outcomes. As part of the study, data was collected by videotaping the teaching-learning activities and interviewing the English teacher. According to the study's findings, the teacher asked specific types of questions. Referential-open questions, which can elicit longer responses, accounted for $31 \%$ of all responses. In contrast, the percentage of display-closed questions was 69 percent. Display/closed questions were frequently used to assess students' understanding of the materials, whereas referential/open questions were frequently used to elicit specific information from students. Words were produced as a result of the use of a display or a closed question. In contrast, students' responses in the form of sentences reached seven sentences. It came as a result of asking open-ended or referring questions (Ahmadi \& Kurniawan, 2020). However, not all types of questions are appropriate for use in the classroom; teachers must recognize that by asking the appropriate questions, the objectives of teaching and learning can be met. Teachers may propose a variety of different types of questions depending on the circumstances. Teachers ask their students to encourage them to take advantage of their learning and development opportunities.

Teachers' questions have an impact on students' motivation to learn because questioning is such an important part of the teaching-learning process. A study was carried out to learn more about the various types of questioning techniques and questions used by English teachers. According to the findings, teachers asked three types of questions: procedural, convergent, and divergent. Meanwhile, the teachers tended to ask convergent rather than divergent procedural questions (Suartini, Wedhanti, \& Suprianti, 2020). In addition, the teacher is expected to encourage students to ask divergent questions in order to engage their critical thinking. A study was also conducted and found that the teacher frequently asks questions about knowledge and comprehension, but rarely about application, analysis, synthesis, or evaluation. According to the study's findings, EFL teachers should be trained in 
questioning strategies to help their students learn more effectively (Cook, Olney, Kelly, \& D'Mello, 2018). Even though the study was conducted in a private school with some unprofessional teachers, these teachers agreed to teach before seeking a better job.

Cook et al. (2018), conducted a related study, and the study's findings stated that teachers in junior and senior high schools ask more knowledge-level questions than teachers in other school levels, and they use a variety of techniques to modify their questions when students do not respond to them. According to both researchers and practicing teachers, the dominance of knowledge level questions, as well as how teachers modified the questions, is influenced by the teachers' competence, the students' competence, the teaching situation, and the teaching material (Ernst-Slavit \& Pratt, 2017). A study found that most of the English teacher's questions were still classified as comprehension questions, which confirmed this. As a result, all the teacher's questions transcribed in relation to the five cognitive levels do not fit into a single category when it comes to organizing questions in classroom interaction by level. The sole purpose of the level would be to elicit factual responses, identify information derived from interpreting meaning, and assess the student's comprehension (Ngadi, 2018). Even though, the information was gathered through an audio recording and transcription of a single English teacher's questions in a classroom. Data should be collected from five to twenty-five teachers (Good, Data, \& Miller, 2000). As a result, more participants should take part in order to improve research findings. Another study was conducted, and the results revealed that most teacher questions were simple cognitively. This finding suggested that teachers questioning patterns in the classroom were unlikely to achieve the policymakers' dual goal of facilitating students' subject learning while also improving their English proficiency (Hu \& Duan, 2018). Even though the study was conducted in 20 subject classes, better results are unlikely due to a lack of objectivity and professionalism. Sundh (2017) conducted similar research and discovered that the teacher used five types of questions: comprehension checks, activity management questions, comprehension and task completion repair questions, and topic elaboration questions. Each question type was used to manage classroom activities at a specific time; however, the findings also show that when questions appear out of context, they can interfere with pedagogical focus and limit students' participation in class. Even though the study was small and based on a single recording. As a result, more information is required to draw more conclusions about the use of questions, the types of responses they elicit, and the relationship between question types and student learning and participation. Another limitation of the study was the lack of access to video recordings, which would have revealed information about eyegaze and other personified actions.

When it comes to determining the best questioning pattern for teaching and learning English as a second or foreign language. Table 1 summarizes the benefits and drawbacks of the most popular and effective question types.

Table 1: Analysis of common Question Types pros and cons

\begin{tabular}{lll}
\hline Question type & Pros & Cons \\
\hline Display questions & $\begin{array}{l}\text { People respond more quickly } \\
\text { and easily in some situations. } \\
\text { The response options provided } \\
\text { by respondents can assist them } \\
\text { in understanding the meaning of } \\
\text { the question. }\end{array}$ & $\begin{array}{l}\text { Participants with no previous knowledge } \\
\text { or opinion are not allowed to respond. } \\
\text { It is easy to become confused when there } \\
\text { are numerous response options. } \\
\text { They allow the teacher to assess } \\
\text { the learner's prior knowledge } \\
\text { and feelings. }\end{array}$ \\
$\begin{array}{ll}\text { desired answer is unavailable or if they } \\
\text { do not know the correct answer. } \\
\text { It's possible that the distinctions between } \\
\text { people's responses will become distorted. } \\
\text { They force people to respond to complex }\end{array}$ \\
& $\begin{array}{l}\text { issues in simplistic ways. } \\
\text { learners are forced to make decisions } \\
\text { they would not have made otherwise. }\end{array}$ \\
\hline
\end{tabular}




\begin{tabular}{|c|c|c|}
\hline $\begin{array}{l}\text { Referential } \\
\text { questions }\end{array}$ & $\begin{array}{l}\text { They support an infinite number } \\
\text { of responses. } \\
\text { They allow respondents to } \\
\text { provide additional information, } \\
\text { qualify their responses, and } \\
\text { clarify their responses. } \\
\text { They allow for appropriate } \\
\text { responses to complex problems. } \\
\text { They stimulate creativity, self- } \\
\text { expression, and detail-oriented } \\
\text { thinking. } \\
\text { They reveal a respondent's logic, } \\
\text { thought process, and frame of } \\
\text { reference. } \\
\text { Respondents are more relaxed } \\
\text { because there are rarely any } \\
\text { correct or incorrect answers. }\end{array}$ & $\begin{array}{l}\text { When it comes to answering questions, } \\
\text { different people respond in varying } \\
\text { degrees of detail. } \\
\text { The responses may be difficult to } \\
\text { compare or statistically analyse. } \\
\text { learners who are well-spoken and well- } \\
\text { read have a competitive advantage. } \\
\text { If the questions are too broad, some } \\
\text { respondents may become disorganized. } \\
\text { There is a greater need for more response } \\
\text { time, forethought, and effort. } \\
\text { Some learners may be intimidated by } \\
\text { these questions. } \\
\text { It takes a long time to finish the answers. }\end{array}$ \\
\hline Closed question & $\begin{array}{l}\text { The ability of the respondent to } \\
\text { communicate is not quite as } \\
\text { important. } \\
\text { Rapid response } \\
\text { It is simpler to respond. }\end{array}$ & $\begin{array}{l}\text { Unable to obtain a comprehensive } \\
\text { response. } \\
\text { Incompetent at coming up with new } \\
\text { ideas } \\
\text { The answer may not fully reflect the } \\
\text { respondent's attitude. } \\
\text { The concepts hint at the correct answers. }\end{array}$ \\
\hline Probing Question & $\begin{array}{l}\text { Encourages students to think } \\
\text { critically in the classroom. } \\
\text { To ensure that you have a } \\
\text { thorough understanding of the } \\
\text { topic } \\
\text { To learn about another person's } \\
\text { thought process } \\
\text { To help with brainstorming } \\
\text { potential solutions }\end{array}$ & It poses a threat to the respondents. \\
\hline Alternative question & $\begin{array}{l}\text { Can test many pieces of content } \\
\text { True-false questions can be used } \\
\text { to evaluate a variety of learning } \\
\text { outcomes. } \\
\text { Grading is quick and easy. } \\
\text { When properly built, can be } \\
\text { extremely accurate in assessing } \\
\text { student knowledge. }\end{array}$ & $\begin{array}{l}\text { It is difficult to distinguish between } \\
\text { students who understand the lesson and } \\
\text { those who do not. } \\
\text { Students are encouraged to memorize } \\
\text { information word for word. } \\
\text { The ability of students to judge the truth } \\
\text { or falsity of propositions related to a } \\
\text { subject determines the extent to which } \\
\text { they understand it. }\end{array}$ \\
\hline
\end{tabular}

The questions listed above are the most common types of questions asked by English language teachers in classroom interactions to assess students' understanding of a topic of discussion. As a result, teachers are encouraged to carefully consider the benefits and drawbacks of the various question types and select one that best suits their students' level, competence, nature of the topic and background. Teachers are more likely to encourage students to participate actively in classroom discussions as a result.

\section{Challenges}

As previously stated, most of the works examined have some sort of implication in some way. The data may not provide us with enough and clear evidence because most of the studies only included one teacher as a participant. Similarly, many studies used only one data collection method, such as a 
questionnaire, audio recording, observation, or interview, without considering the value of triangulating the various data collection methods for a work. So that the finding may accept validity and usefulness. Furthermore, regardless of class or level, the majority of the works were managed to complete, allowing readers to understand and be informed about the study's topics. Another strong implication of some of the works was that different teachers were used for different subjects, implying that better results are unlikely due to a lack of objectivity and professionalism. Questions are asked in accordance with the nature of the subject and topic being taught in the classroom. As a result, coming to a valid conclusion about this discovery will be critical. Because some topics accommodate specific types of questions while others do not. According to a study, not all types of questions are relevant for every topic in classroom interaction, which supports this claim. (Questions, Classroom, \& Kunci, 2002).

\section{Conclusion}

The purpose of teachers' classroom questions is to recognize and comprehend the students' level of understanding of what has been taught in the classroom, as well as to connect the actions to the participants. Because teachers' questions are found to be a type of better teaching and learning pattern. The goal of the questioning pattern used by English teachers is to improve learners' language competence and fluency while also connecting classroom activities. Teachers are expected to use modern questioning approaches rather than traditional questioning methods because they perform better at associating each event with a series of activities rather than a single activity and correctly predicting. Many researchers advocated for more techniques to address issues related to teachers' questioning patterns in English classes, such as reducing the dimensionality and complexity of multiple classroom activities. However, there is still room for advancement and the creation of a unified or better model for detecting a high-profile questioning pattern in the classroom setting. Given the preceding discussion, it is clear that most teachers need a better understanding of how to select and use questions in the classroom, taking into account a variety of factors such as the student's current level, background knowledge, level of competence, time constraints, and teacher-to-student ratio.

\section{References}

Ahmadi, \& Kurniawan, E. (2020). Teachers' Questions in Indonesian Efl Classroom. JL3T ( Journal of Linguistics Literature and Language Teaching), 6(1), 1-11. https://doi.org/10.32505/j13t.v6i1.1355

Cook, C., Olney, A. M., Kelly, S., \& D'Mello, S. K. (2018). An open vocabulary approach for estimating teacher use of authentic questions in classroom discourse. Proceedings of the 11th International Conference on Educational Data Mining, EDM 2018, (Example 1).

D, A. O. P., \& Oluyemi, E. (2020). Modified Questioning Strategy in small class size and its comparative effect on Academic Achievement of students in Physics and Human Kinetic and Health Education : A pilot study. 10(3), 46-52. https://doi.org/10.9790/7388-1003014652

Dobber, M., Zwart, R., Tanis, M., \& van Oers, B. (2017). Literature review: The role of the teacher in inquiry-based education. Educational Research Review, 22, 194-214. https://doi.org/10.1016/j.edurev.2017.09.002

Ernst-Slavit, G., \& Pratt, K. L. (2017). Teacher questions: Learning the discourse of science in a linguistically diverse elementary classroom. Linguistics and Education, 40, 1-10. https://doi.org/10.1016/j.linged.2017.05.005

Good, G., Data, Q., \& Miller, D. L. (2000). De te r m in ing Vali d i t y in Qu ali ta tive In qu ir y. 39(3).

Handeland, I. (2020). Classroom discourse in L2 English instruction.

Hu, G., \& Duan, Y. (2018). International Journal of Bilingual Education and Questioning and responding in the classroom : a cross-disciplinary study of the effects of instructional mediums in academic subjects at a Chinese university. International Journal of Bilingual Education and Bilingualism, O(0), 1-19. https://doi.org/10.1080/13670050.2018.1493084

Jumare, D. A. M. (2020). Impact of Teachers' Quality on Students 'Academic Performance in 
Secondary Schools in North Central * Usman Mohammed and ** Dr. Abubakar M. Jumare. $18(8), 1-16$.

Khadka, J. (2021). Teachers' Questioning: A Survey of Nepali Schools. International Journal of Social Sciences and Management, 8(1), 333-340. https://doi.org/10.3126/ijssm.v8i1.34115

Lee, Y., \& Kinzie, M. (2014). Teacher question and student response with regard to cognition and language use. (February). https://doi.org/10.1007/s11251-011-9193-2

Mccomas, W. F., \& Abraham, L. (1991). American Journal of Instruction. (1956).

Muller, T., Herder, S., Adamson, J., \& Brown, P. S. (2011). Innovating EFL teaching in Asia. Innovating EFL Teaching in Asia, (October), 1-301. https://doi.org/10.1057/9780230347823

Mutai, N. C. (2012). A Critical Review of Oral Questioning Technique in Secondary School English Language Teaching in Eldoret Municipality, Kenya. Journal of Emerging Trends in Educational Research and Policy Studies, 3(3), 323-330. Retrieved from http://journals.co.za/content/sl_jeteraps/3/3/EJC140938

Nevtria, S., \& Puspita, H. (2020). An Analysis of Pr ofessional Teachers 'Questions in EFL Classroom. (2013), 85-96.

Ngadi, Y. F. (2018). An Analysis of Questions and Answers in an EFL Classroom of St . Joseph Junior High School in Academic Year 2015 / 2016. 1(2), 48-54.

Qashoa, S. (2013). Effects of teacher question types and syntactic structures on EFL classroom interaction. The International Journal of Social Sciences, 7(1), 52-62.

Questions, P., Classroom, E. F. L., \& Kunci, K. (2002). Teacher' S Probing Questions In The Efl Classroom At A High School Nihayatul Mutimmah Abstrak. (1993), 59-68.

Rachmawaty, N., \& Ariani, S. (2019). Investigating The Types of Teacher Questions in EFL Secondary Classroom. 276(Icoelt 2018), 40-49. https://doi.org/10.2991/icoelt-18.2019.6

Suartini, N. K. T., Wedhanti, N. K., \& Suprianti, G. A. P. (2020). Teacher 's Questioning Strategies in Junior High School: A Case Study. (2), 97-103.

Sundh, L. (2017). The function of teacher questions in EFL classroom activities in Cambodia A conversation analytic study The function of teacher questions in EFL classroom activities in. 132.

Yusuf, A., \& Tambuwal, I. N. (2020). During Teacher Preparation Programme : A Grounded Theory Stem Classrooms During Teacher Preparation. (September). 